\title{
Recovery of deep-water megafaunal assemblages from hydrocarbon drilling disturbance in the Faroe-Shetland Channel
}

\author{
Daniel O. B. Jones ${ }^{1, *}$, Andrew R. Gates ${ }^{1}$, Berthold Lausen ${ }^{2}$ \\ ${ }^{1}$ National Oceanography Centre, European Way, Southampton SO14 3ZH, UK \\ ${ }^{2}$ Department of Mathematical Sciences, University of Essex, Wivenhoe Park, Colchester CO4 3SQ, UK
}

\begin{abstract}
Recovery of megabenthic assemblages from physical disturbance at the Laggan deep-water hydrocarbon drilling site in the Faroe-Shetland Channel was assessed using remotely operated vehicle quantitative video survey. Twelve undisturbed control sites and 2 well sites (A and $\mathrm{C}$, disturbed 3 and $10 \mathrm{yr}$ prior to this work, respectively) were analysed and compared with a previous survey immediately following disturbance at A. The megabenthic epifauna at Laggan was dominated by sponges (69.6\% total fauna) represented by 20 taxa. Cnidarians $(12.8 \% ; 9$ taxa) and echinoderms $(7.1 \% ; 11$ taxa) were also common. Diversity was generally high and typical for the cold waters of the Faroe-Shetland Channel. Two distinct assemblages were found: one in the deeper area of the study site (also incorporating Site C), and one in the other areas (incorporating Site A). Motile faunal densities and richness were significantly elevated immediately after drilling in an area with intermediate disturbance, presumably attracted to available carcasses of organisms killed by drilling disturbance. After 3 and $10 \mathrm{yr}$, densities of motile organisms were less variable with distance, except very close to drilling where densities and richness were still reduced. Sessile faunal densities and richness increased significantly with increasing distance from drilling in all years, although both metrics were significantly higher close to drilling after 3 and 10 yr when compared to immediately after drilling. These data suggest partial megabenthic recovery between 3 and 10 yr post-disturbance. Despite this, in the area remaining completely covered by drill cuttings there were few megafauna observed even after $10 \mathrm{yr}$.
\end{abstract}

KEY WORDS: Recovery $\cdot$ Megafauna $\cdot$ Disturbance $\cdot$ Benthic $\cdot$ Deep-sea $\cdot$ Hydrocarbon drilling Remotely operated vehicle video $\cdot$ ROV video

Resale or republication not permitted without written consent of the publisher

\section{INTRODUCTION}

Disturbance from typical best-practice hydrocarbon drilling generally causes sedimentation and some chemical stress to benthic communities, rarely measurable beyond $250 \mathrm{~m}$ of the drilled area (Jones et al. 2007b, Santos et al. 2009). With increasing drilling activity in deeper waters (Radler 2006), and in environmentally sensitive areas, disturbance from drilling is an increasing threat to benthic ecosystems across the globe. The UK continental shelf and slope has around $0.3 \%$ of the world's proven hydrocarbon reserves (Radler 2006), much of which is in the Faroe-Shetland Channel. With studies highlighting the effects of declining biodiversity on ecosystem functioning in the deep sea (Danovaro et al. 2008), it is important to understand the losses being experienced and the potential for recovery.

The megabenthos play a key role in the functioning of deep-sea ecosystems (Smith \& Hamilton 1983), and they are important to include in environmental studies. Megabenthic organisms are difficult to study 
using conventional sampling methods because of their low density. In addition, in rocky areas, such as the Faroe-Shetland Channel, trawled gear and their catch are typically badly damaged when retrieved (Thomson 1873). Recovery in epibenthic megafaunal assemblages after anthropogenic disturbance is rarely investigated as it requires multi-year assessment over large areas at high-resolution.

The impact of hydrocarbon exploration drilling at the Laggan field in the Faroe-Shetland Channel includes complete smothering of the seabed with drill cuttings (composed of sediments and drill mud; see Schaanning et al. 2008) up to $120 \mathrm{~m}$ from the well and a subsequent significant reduction in megafaunal abundance and diversity (Jones et al. 2006). In addition to disturbance from smothering, potential ecotoxicological effects of components of the drilling muds (Terzaghi et al. 1998, Schaanning et al. 2008, Trannum et al. 2010) and changes in sediment grain size from coarse to fine may have reduced recovery rates (Trannum et al. 2010). Hydrocarbon drilling, as a known and quantifiable disturbance, provides a useful model for studying the effects of anthropogenic disturbance in the deep sea.

Recovery typically implies a return of an ecosystem to pre-disturbance conditions as a result of the operation of homeostatic ecological control mechanisms (O’Neill 1998). Recovery is a complex phenomenon involving spatially and temporally dynamic biotic and abiotic changes. The recovered ecosystem may have altered in some way from its original state, for example in ecosystem function, structure, species complement or diversity (O’Neill 1998). Although disturbance to megafaunal assemblages from drilling has been reported (Jones et al. 2006, 2007b, Hughes et al. 2010), there have been few assessments of recovery associated with deep-water drilling impacts.

\section{Study area}

The Faroe-Shetland Channel is a deep channel separating the Faroe Plateau from the Scottish continental shelf (Fig. 1). It has a complex hydrographic regime, with warm North Atlantic waters overlying the cold water flowing from the Norwegian Sea (Turrell et al. 1999, Bett 2001). At $600 \mathrm{~m}$ depth, the Laggan oil field (Fig. 1) is located at the transition between warmer and colder water masses: Arctic Intermediate Water (400 to $600 \mathrm{~m} ; 2$ to $5.5^{\circ} \mathrm{C}$ ) and Norwegian Sea Arctic Intermediate Water ( -0.5 to $0.5^{\circ} \mathrm{C}$ in 600 to $800 \mathrm{~m}$ ) (Turrell et al. 1999). The deepwater thermocline, at approximately $550 \mathrm{~m}$ depth in

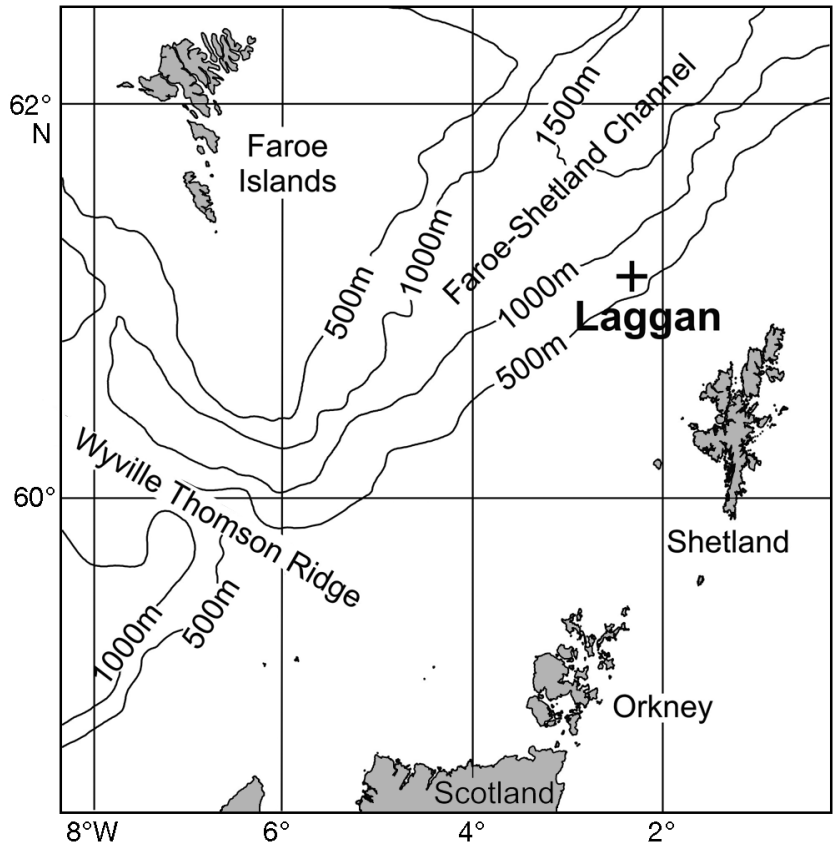

Fig. 1. Location of the Laggan study site in the FaroeShetland Channel

the Laggan area, can vary in depth by more than $40 \mathrm{~m}$ during a tidal cycle (Sherwin 1995).

The Faroe-Shetland Channel harbours a wide variety of megafaunal species (Bett 2001). The abundance of hard substratum (iceberg rafted drop stones) generally leads to a well-developed encrusting epifauna of poriferans, cnidarians and bryozoans. On softer substrata, echinoderms are abundant (Bett 2001, Jones et al. 2007a). There is a distinct community separation between the different temperature regimes in the channel in all faunal groups investigated (Bett 2001, Narayanaswamy et al. 2005, Witbaard et al. 2005, Jones et al. 2007a).

The Laggan area (Well 206/1a-4-az; here Well A) was subject to a detailed investigation of the initial effects of drilling disturbance in 2004 on the benthic megafaunal assemblage (Jones et al. 2006). Two wells studied in the warmer shallower waters of the Faroe-Shetland Channel revealed different species but similar disturbance regimes and responses of megafauna to disturbance (Jones et al. 2007b).

\section{Aims}

The objectives of this study are to determine the recovery of deep-water megafaunal density and diversity after physical anthropogenic disturbance in the Faroe-Shetland Channel. 


\section{MATERIALS AND METHODS}

\section{Survey design}

The study was undertaken in April 2007 and had 3 study targets:

(1) Drill Site A-drilled in March 2004 ; i.e. studied 3 yr after drilling (also surveyed previously, in April 2004, by Jones et al. 2006)

(2) Drill Site C - drilled in 1997; i.e. studied $10 \mathrm{yr}$ after drilling (not surveyed previously; drilled using a similar method to A)

(3) Background environment-randomly selected locations at least $500 \mathrm{~m}$ from the drilling sites and presumed to be beyond the influence of acute drilling impacts (see e.g. Jones et al. 2006). These locations were divided equally between 2 depth strata, based on the approximate transition depth $(600 \mathrm{~m})$ between the shallower Arctic Intermediate Water and the deeper Faroe-Shetland Channel Bottom Water (Turrell et al. 1999) and associated changes in biology (Bett 2001).

The background environment samples at Laggan (Fig. 2) were constrained to a $6 \times 6 \mathrm{~km}$ square (corners: NW 6759873 N, 502888 E; NE 6759873 N, 508888 E; SE 6753873 N, 508888 E; SW 6753873 N, 502888 E; Fig. 2). All positional information was recorded in Universal Transverse Mercator (UTM) zone $30 \mathrm{~N}$, based on the World Geodetic Society 1984 datum. The 2 well sites were located as follows: A at $6756872.9 \mathrm{~N}, 505887.6 \mathrm{E}$ (drilling commenced on 25 March 2004) and C at 6758191.0 N, 503849.5 E (drilled in 1997).

\section{Data collection}

Data were collected using a Seaeye Tiger remotely operated vehicle (ROV) equipped with a colour video camera, digital still camera (Kongsberg OE14-208), sonar (Tritech) and ultra-short baseline navigation transponder. Before each transect, the camera was centred, fully zoomed out and tilted to its most vertical angle ( $47^{\circ}$ below horizontal) to optimise scaling of oblique images.

Well site surveys were radiating video transects, $500 \mathrm{~m}$ in length (Fig. 2, Table S1 in the supplement at www.int-res.com/articles/suppl/m461p071_supp.pdf; Site $A: n=8$, Site C: $n=4$ ). Each transect was split into $100 \mathrm{~m}$ sections by distance from the well (5 distance zones: 0-100 m, 100-200 m, 200-300 m, 300-400 $\mathrm{m}$ and 400-500 $\mathrm{m}$; Site A: $\mathrm{n}=40$, Site C: $\mathrm{n}=$ 20). The seabed water depth along transects was 595 to $601 \mathrm{~m}$ for Site A and 631 to $640 \mathrm{~m}$ for Site C.

Video transects designed to characterise the natural seabed conditions (prefix $\mathrm{R}_{i}$ Table $\mathrm{S} 1$ in the supplement; $\mathrm{n}=12$; length $=100 \mathrm{~m}$ ) commenced from pre-defined random positions on random headings within the 2 depth strata (6 transects in 550 to $600 \mathrm{~m}$ and 6 in 600 to $650 \mathrm{~m}$ water depth). Transect 5 was subsequently excluded from the analysis as a fault with the ROV caused loss of video quality. Although the survey design initially separated random transects into 2 strata based on the $600 \mathrm{~m}$ contour, random transects shallower than $611 \mathrm{~m}$ and deeper than $633 \mathrm{~m}$ were found to be distinctly different (see 'Results'). Random transects were subsequently divided by depth into 2 groups, $R_{\text {shallow }}$ and $R_{\text {deep }}$ (see 'Results'). Sampling units for all analysis consisted of segments of video repre- 
senting $100 \mathrm{~m}^{2}$ of seabed $(\mathrm{n}=71$ for the 2007 study). Faunal counts are total counts for this $100 \mathrm{~m}^{2}$ area. The 2004 dataset (Jones et al. 2006) provided an additional 18 sampling units in both the $0-100 \mathrm{~m}$ and $100-200 \mathrm{~m}$ zones $(\mathrm{n}=36$ for the 2004 study). There were insufficient data in the 2004 dataset to assess changes beyond $200 \mathrm{~m}$ from the well. Control sites were not assessed in 2004 . Unfortunately, this precludes estimation of natural temporal variation in the background fauna and prevented a full BACI (Before After Control Impact) design being followed (Underwood 1994).

In every transect, the ROV was run in a straight line, on a set bearing, at a constant speed $\left(\sim 0.3 \mathrm{~m} \mathrm{~s}^{-1}\right)$ and set altitude $(0.2 \mathrm{~m})$. Transect width (mean of $1.0 \mathrm{~m}_{i}$ maximum variation $\pm 0.2 \mathrm{~m}$ ) was calculated from the camera acceptance angles and verified following Jones et al. (2006). The optical resolution of the cameras permitted all organisms larger than $50 \mathrm{~mm}$ to be reliably distinguished. In addition to the transects, previous ROV suction sampling, detailed inspection and still photography of selected individual organisms aided species identifications (Jones \& Gates 2010).

Prior to this survey, quantitative video transects were conducted at Laggan Site A in 2004 using an industry-operated work-class Clansman ROV (Jones 2009). Other than the ROV and camera system being different models, an identical methodology was used in that study (Jones et al. 2006), enabling direct comparison of the data obtained from both surveys.

\section{Data analysis}

Fauna were enumerated from video following the methods of Jones et al. (2006). It was frequently not possible to identify organisms to known species, and fauna were classified into separate morphologically distinguishable entities (referred to as taxa). Numbers of organisms were quoted as abundances (numbers in each sampling unit) or as densities (no. $\mathrm{m}^{-2}$ ). In addition, observations were made describing the horizontal extent of the drill cuttings and the natural state of the seabed. These were categorised as complete coverage (where more than $90 \%$ of the sea bed was covered) and partial coverage (where there was some visual evidence of drill cuttings on the sea bed). Estimates of area disturbed were made by analysing maps in Image J software (v1.41, National Institutes of Health).

Univariate diversity indices were calculated to assess the dominance (Pielou's evenness) and species richness (the number of species) aspects of diversity (Magurran 2003). The common Shannon-Wiener index was also presented for comparison with other studies. Shannon-Wiener and Pielou's evenness were calculated using PRIMER (v6).

Four generalized linear (GLM) statistical models were independently developed (Dobson \& Barnett 2008) to examine whether the density (no. $\mathrm{m}^{-2}$ ) and taxon richness (number of species in a sample unit) of both sessile and motile megafauna at Laggan could be explained using the explanatory variables distance, depth group and year. Random sites were coded with a distance of $>1000 \mathrm{~m}$ from drilling and included in all analysis. An additional GLM was developed for overall assemblage evenness with the same explanatory variables as above. All 3 explanatory variables were treated as categorical data. The residual deviance (1652.5 for sessile; 473.6 for motile) was greater than the residual degrees of freedom (91 for both), indicating overdispersion. The model was, therefore, fitted with quasi-Poisson errors using the $\mathrm{R}$ function glm and the ANOVA function of the $\mathrm{R}$ package CAR (companion to applied regression) (Fox \& Weisberg 2011) in the $\mathrm{R}$ programming environment ( $\mathrm{R}$ Development Core Team 2010).

\section{Assessment of recovery}

Recovery is indicated by a reduction in magnitude of the gradient in disturbance that occurs with distance from drilling. In the shallow samples (Drill Site $A$ and $R_{\text {shallow }}$ ), evidence for recovery was provided by the significance and direction of the statistical interaction between time since disturbance (year) and distance from drilling (distance). Recovery was suggested by a reduction in the variation in the response variable (e.g. sessile faunal density) with distance from 2004 to 2007. Further evidence of recovery at Laggan was provided by the significance and direction of the statistical interaction between the distance from drilling (drilling) and the well site (depth zone). Recovery was suggested by a reduction in the variation in the response variable with distance in the samples from the deeper zone (sampled $10 \mathrm{yr}$ after drilling) compared to the shallower zone (sampled $3 \mathrm{yr}$ after drilling). It should be noted that changes in response variables between the shallow and deep zones at Laggan should be treated with caution, as specific responses across distance zones may have differing drivers with disparity in the assemblage composition. 


\section{RESULTS}

\section{The background environment at Laggan}

Benthic megafaunal density was variable in background areas (Table 1), and their fine-scale $\left(<100 \mathrm{~m}^{2}\right)$ distribution appeared to be primarily governed by substratum type and the availability of suitable microhabitats. Most sessile filter feeders were attached to hard substrata. Echinoderms generally were found on finer sediments, being common in gravel and sand areas. The megabenthic epifauna at Laggan (in 2007; Tables 1 \& 2) was dominated by sponges (20 taxa). Echinoderms (11 taxa) and cnidarians (9 taxa) were also important.

The total density of fauna varied over nearly an order of magnitude (Table 1) between the background samples (6.41 [R7] to $0.9 \mathrm{~m}^{-2}$ [R8]). Three

Table 1. Taxon abundances (per $100 \mathrm{~m}^{2}$ sampling unit; averaged for groups) from the present survey and that of Jones et al. (2006); $\mathrm{R}_{\text {shallow }}=$ background samples $<615 \mathrm{~m}$ depth; $\mathrm{R}_{\text {deep }}=$ background samples $>615 \mathrm{~m}$ depth. Distance zones, i.e. distance from well: $0-100,100-200,200-300,300-400$ and 400-500 m. Indet $=$ Indeterminate. Taxonomic precision given where applicable: ${ }^{a}$ identified from specimens; ${ }^{b}$ confident identification from high-resolution photograph (Jones \& Gates 2010); ${ }^{\mathrm{C}}$ low confidence identification; ${ }^{d}$ motile megafauna. A,C: sites

\begin{tabular}{|c|c|c|c|c|c|c|c|c|c|c|c|c|c|c|}
\hline & $\mathrm{R}_{\text {shallow }}$ & $\mathrm{R}_{\text {deep }}$ & $\begin{array}{c}200 \\
0- \\
100\end{array}$ & $\begin{array}{c}4 \mathrm{~A} \\
100- \\
200\end{array}$ & $\begin{array}{c}0- \\
100\end{array}$ & $\begin{array}{l}100- \\
200\end{array}$ & $\begin{array}{c}2007 \text { A } \\
200- \\
300\end{array}$ & $\begin{array}{c}300- \\
400\end{array}$ & $\begin{array}{c}400- \\
500\end{array}$ & $\begin{array}{c}0- \\
100\end{array}$ & $\begin{array}{c}100- \\
200\end{array}$ & $\begin{array}{c}2007 \mathrm{C} \\
200- \\
300\end{array}$ & $\begin{array}{c}300- \\
400\end{array}$ & $\begin{array}{c}400- \\
500\end{array}$ \\
\hline Sponge A & 0.3 & 0.0 & 0 & 0 & 0 & 0.1 & 0 & 0.1 & 0 & 0 & 0 & 0 & 0 & 0 \\
\hline Sponge B & 0.3 & 4.7 & 0 & 0 & 3.5 & 8.4 & 9.6 & 8.3 & 4.5 & 1.5 & 1.0 & 2.0 & 0.3 & 0.8 \\
\hline $\begin{array}{r}\text { Spherical } \\
\text { sponge }\end{array}$ & 16.8 & 56.0 & 0.1 & 0.9 & 19.1 & 40.4 & 44.8 & 43.0 & 35.3 & 87.3 & 82.0 & 48.8 & 61.5 & 58.9 \\
\hline Sponge F & 7.9 & 10.7 & 0 & 0 & 3.9 & 11.5 & 13.8 & 11.1 & 10.3 & 20.5 & 16.8 & 12.5 & 18.3 & 23.6 \\
\hline Sponge H & 5.3 & 24.0 & 0 & 0 & 10.8 & 24.5 & 27.8 & 23.5 & 15.9 & 10.0 & 13.5 & 9.3 & 13.3 & 15.8 \\
\hline Sponge I & 1.5 & 1.7 & 0 & 0 & 0.1 & 0 & 0 & 0.5 & 0.3 & 0 & 0 & 0 & 0 & 0 \\
\hline Sponge J & 5.3 & 11.0 & 0 & 0 & 8.5 & 22.3 & 20.3 & 18.0 & 14.9 & 7.5 & 8.0 & 8.3 & 7.3 & 8.5 \\
\hline Sponge K & 2.0 & 3.3 & 0 & 0 & 2.1 & 3.1 & 3.1 & 2.1 & 2.4 & 0.3 & 0 & 0 & 1.5 & 0.3 \\
\hline Sponge L & 1.1 & 1.7 & 0.1 & 0.3 & 13.5 & 18.1 & 11.3 & 6.5 & 8.9 & 2.0 & 0.5 & 2.0 & 3.0 & 2.4 \\
\hline Sponge M & 7.3 & 1.7 & 0 & 0.1 & 4.3 & 9.1 & 8.8 & 8.8 & 6.4 & 1.3 & 2.0 & 0.8 & 0.8 & 0.5 \\
\hline Sponge N & 9.4 & 22.3 & 0 & 0 & 1.0 & 1.1 & 1.5 & 0.9 & 2.3 & 0.3 & 0.5 & 0 & 0 & 0.8 \\
\hline $\begin{array}{l}\text { Indet. white } \\
\text { encrusting sponge }\end{array}$ & 15.9 & 10.7 & 1.3 & 13.4 & 7.6 & 23.4 & 29.5 & 28.3 & 27.1 & 19.5 & 19.0 & 20.5 & 15.0 & 11.3 \\
\hline $\begin{array}{l}\text { Indet. yellow } \\
\text { encrusting sponge }\end{array}$ & 3.0 & 6.0 & 0.1 & 1.1 & 1.3 & 6.0 & 7.9 & 7.0 & 6.1 & 1.3 & 1.0 & 2.5 & 0 & 1.4 \\
\hline $\begin{array}{l}\text { Indet. red } \\
\text { encrusting sponge }\end{array}$ & 1.5 & 0 & 0 & 0 & 0.5 & 0.4 & 0.1 & 0.3 & 0 & 0 & 0.5 & 0 & 0.3 & 0.3 \\
\hline $\begin{array}{l}\text { Indet. tall cylin- } \\
\text { drical sponge }\end{array}$ & 11.3 & 6.7 & 0 & 0 & 0.8 & 2.6 & 8.1 & 4.3 & 3.6 & 8.8 & 4.0 & 5.0 & 7.5 & 10.4 \\
\hline $\begin{array}{l}\text { Stylocordyla } \\
\text { borealis }\end{array}$ & 0.9 & 2.0 & 0 & 0.1 & 0 & 0.3 & 0.4 & 0.1 & 0.4 & 1.0 & 1.0 & 1.5 & 1.0 & 2.4 \\
\hline Geodia sp. & 0.8 & 13.3 & 0 & 0 & 0 & 0.1 & 0.3 & 0 & 0 & 0 & 0 & 0 & 0 & 0.3 \\
\hline $\begin{array}{l}\text { Indet. brown } \\
\text { digitate sponge }\end{array}$ & 0 & 2.3 & 0 & 0 & 1.0 & 1.0 & 1.0 & 1.4 & 1.4 & 0.8 & 1.5 & 0.8 & 0.5 & 0.6 \\
\hline $\begin{array}{l}\text { Chondrocladia } \\
\text { gigantea }^{\mathrm{a}}\end{array}$ & 0 & 0 & 0 & 0 & 0 & 0 & 0 & 0.1 & 0 & 0.3 & 0.5 & 0 & 0 & 0.3 \\
\hline $\begin{array}{l}\text { Indet. white } \\
\text { small sponges }\end{array}$ & 4.9 & 6.0 & 0.8 & 15.4 & 0 & 1.9 & 7.1 & 9.6 & 11.0 & 29.5 & 12.3 & 19.3 & 13.8 & 16.3 \\
\hline Tubularia regalis ${ }^{\mathrm{c}}$ & 0 & 0 & 0 & 0 & 0 & 0 & 0 & 0 & 0 & 0 & 0.3 & 0 & 0 & 0 \\
\hline $\begin{array}{l}\text { Corymorpha } \\
\text { gronlandica }^{\mathrm{a}}\end{array}$ & 0.1 & 0.3 & 0 & 0 & 0 & 0 & 0 & 0 & 0 & 0 & 0 & 0.3 & 0.3 & 0 \\
\hline $\begin{array}{l}\text { Drifa glomerata } \mathrm{A} \\
\text { (white) }\end{array}$ & 1.8 & 14.3 & 0 & 0 & 0.9 & 0.1 & 0.4 & 0.1 & 0.1 & 3.0 & 3.8 & 1.5 & 0.5 & 1.6 \\
\hline Gersemia sp..$^{\mathrm{C}}$ (blue) & 0 & 6.0 & 0 & 0.4 & 0.1 & 0.3 & 0.4 & 0.1 & 0.4 & 46.3 & 27.0 & 29.5 & 34.8 & 37.8 \\
\hline Gersemia sp. ${ }^{\mathrm{c}} \mathrm{C}$ (pink) & 0 & 5.7 & 0 & 0 & 0 & 0 & 0 & 0 & 0 & 3.3 & 0.3 & 2.8 & 2.8 & 2.4 \\
\hline Gersemia sp. ${ }^{\mathrm{c}} \mathrm{D}$ (red) & 0.1 & 22.3 & 0 & 0 & 0 & 0 & 0 & 0 & 0 & 53.8 & 36.0 & 32.5 & 38.8 & 32.9 \\
\hline Indet. actiniarian & 0.8 & 0 & 0 & 0 & 0.3 & 0 & 0 & 0 & 0 & 0 & 0.3 & 0 & 0 & 0 \\
\hline Bolocera sp. ${ }^{\mathrm{c}}$ & 4.5 & 4.3 & 0.2 & 1.4 & 2.6 & 1.9 & 1.9 & 3.8 & 2.4 & 0.8 & 3.0 & 2.0 & 1.8 & 1.6 \\
\hline Halcampa arctica ${ }^{a}$ & 0.5 & 3.0 & 0 & 0 & 0 & 0 & 0 & 0.5 & 0.9 & 1.8 & 6.0 & 5.3 & 5.5 & 8.1 \\
\hline Sabellid & 1.9 & 190.3 & 0 & 0 & 0.4 & 0.4 & 1.1 & 1.3 & 0.6 & 0.3 & 1.3 & 0.5 & 1.8 & 5.3 \\
\hline Colus sp. ${ }^{\mathrm{b}, \mathrm{d}}$ & 1.5 & 0.7 & 0 & 0.3 & 0.9 & 0.5 & 0.1 & 0.4 & 0.6 & 1.0 & 1.3 & 0.8 & 1.0 & 0 \\
\hline
\end{tabular}


Table 1 (continued)

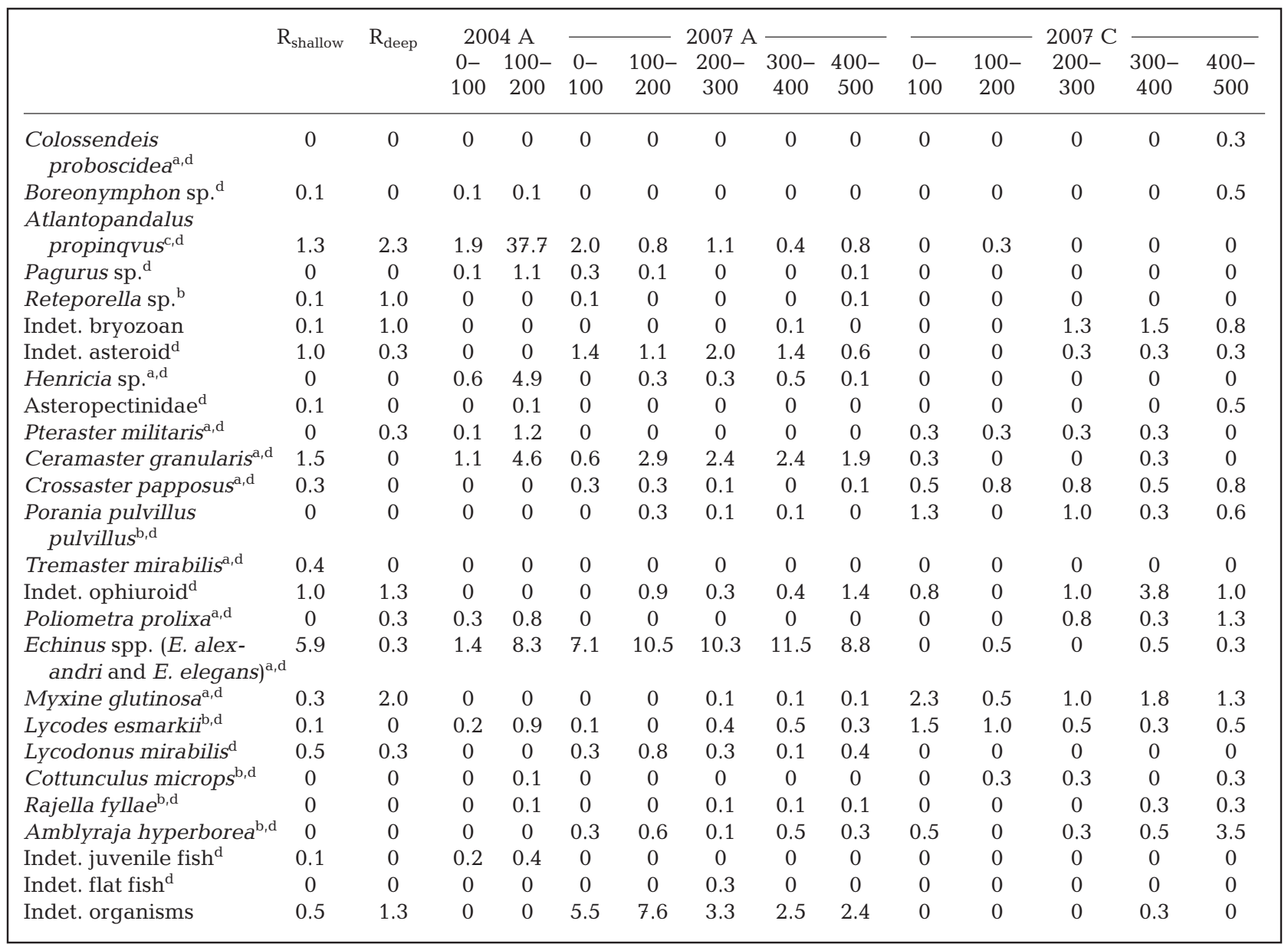

Table 2. Proportional abundance of each megafaunal phylum observed at Laggan (\%). See Table 1 for definitions

\begin{tabular}{|c|c|c|c|c|c|c|c|c|c|c|c|c|c|c|}
\hline & $\mathrm{R}_{\text {shallow }}$ & $\mathrm{R}_{\text {deep }}$ & $\begin{array}{c}200 \\
0- \\
100\end{array}$ & $\begin{array}{c}24 \mathrm{~A} \\
100- \\
200\end{array}$ & $\begin{array}{c}0- \\
100\end{array}$ & $\begin{array}{c}\overline{100-} \\
200\end{array}$ & $\begin{array}{c}2007 \text { A } \\
200- \\
300\end{array}$ & $\begin{array}{c}300- \\
400\end{array}$ & $\begin{array}{c}400- \\
500\end{array}$ & $\begin{array}{c}0- \\
100\end{array}$ & $\begin{array}{c}100- \\
200\end{array}$ & $\begin{array}{c}2007 \mathrm{C} \\
200- \\
300\end{array}$ & $\begin{array}{c}300- \\
400\end{array}$ & $\begin{array}{c}400- \\
500\end{array}$ \\
\hline Porifera & 79.6 & 41.7 & 21.0 & 33.9 & 79.2 & 86.1 & 88.1 & 83.4 & 84.6 & 63.0 & 65.6 & 64.0 & 62.8 & 62.1 \\
\hline Cnidaria & 6.5 & 12.7 & 3.5 & 1.9 & 4.1 & 1.2 & 1.3 & 2.9 & 2.2 & 34.2 & 31.6 & 32.1 & 31.7 & 30.0 \\
\hline Mollusca & 1.3 & 0.2 & 0.0 & 0.2 & 0.7 & 0.2 & 0.1 & 0.1 & 0.4 & 0.4 & 0.7 & 0.3 & 0.4 & 0.0 \\
\hline Annelida & 1.6 & 43.1 & 0.0 & 0.0 & 0.2 & 0.2 & 0.4 & 0.6 & 0.3 & 0.1 & 0.4 & 0.3 & 0.8 & 1.8 \\
\hline Arthropoda & 1.2 & 0.5 & 14.1 & 39.8 & 2.2 & 0.5 & 0.6 & 0.1 & 0.5 & 0.0 & 0.1 & 0.0 & 0.0 & 0.3 \\
\hline Echinodermata & 8.5 & 0.6 & 35.5 & 22.4 & 9.1 & 7.8 & 7.2 & 10.0 & 9.2 & 0.8 & 0.7 & 1.8 & 2.6 & 1.8 \\
\hline Bryozoa & 0.2 & 0.5 & 0.0 & 0.0 & 0.1 & 0.0 & 0.0 & 0.0 & 0.2 & 0.0 & 0.0 & 0.5 & 0.5 & 0.3 \\
\hline Vertebrata: Pisces & 1.3 & 0.8 & 3.7 & 1.8 & 0.6 & 0.7 & 0.6 & 0.8 & 0.6 & 1.6 & 0.9 & 1.0 & 1.2 & 2.1 \\
\hline
\end{tabular}

samples had high total densities (4.21 [R3], 2.63 [R6], $\left.6.41[\mathrm{R} 7]_{\mathrm{m}}^{-2}\right)$. The other samples had similar densities (mean $1.2 \mathrm{~m}^{-2} \pm 0.19 \mathrm{~m}^{-2} \mathrm{SD}$ ). Sabellids were almost exclusive to 2 samples $\left(\mathrm{R} 3=2.17 \mathrm{~m}^{-2}, \mathrm{R} 7=\right.$ $3.54 \mathrm{~m}^{-2}$; other samples $<0.06 \mathrm{~m}^{-2}$ ) and only found in fine sediment. The samples with the highest total number of taxa $(S)$ were R7 (31), R3 (28) and R6 (27);
R1 had the lowest $S$ (19). Evenness was clearly reduced in samples R7 $\left(J^{\prime}=0.56\right)$ and R3 $\left(J^{\prime}=0.59\right)$ compared to the other samples $\left(J^{\prime}=0.82\right.$ to 0.89$)$, owing to high sabellid densities.

There was a clear separation in assemblage composition of background sites, with 2 distinct groups. Ten taxa were unique to $\mathrm{R}_{\text {shallow }}$ and 5 were only 
found in $\mathrm{R}_{\text {deep }}$ (Table 1$)$. One group (R1, 2, 4, 8, 9, 10, 11, 12) was sampled in shallower water (562 to $610 \mathrm{~m}$ ) and the other $(\mathrm{R} 3,6,7)$ in deeper water (634 to $637 \mathrm{~m})$. All background images show a heterogeneous seabed composed of fine sediments, gravel and occasionally cobbles and boulders, but the proportion of these visible grain sizes varied between samples. Most samples had a predominance of sandy gravel, with cobbles and occasional boulders. Samples R3 and R7 had a visible reduction in dominant sediment grain size, confirmed in concurrent sediment samples (see Table S2 in the supplement at www.int-res.com/ articles/suppl/m461p071_supp.pdf).

The survey of background sites was designed to have 2 depth strata, with a division at $600 \mathrm{~m}$ water depth. The preceding analysis suggests that the faunal division was located a little deeper than predicted, between 610 and $634 \mathrm{~m}$. This was important in subsequent analysis of recovery at the well sites. Site A (595 to $601 \mathrm{~m}$ ) transects were in the shallower zone and Site C (631 to $640 \mathrm{~m}$ ) transects were in the deeper zone. As a result, in subsequent analysis, Samples R1, 2, 4, 8, 9, 10, 11 and 12 (collectively referred to as $\mathrm{R}_{\text {shallowi }} \mathrm{n}=8$ ) were considered to represent background samples for Site A and Samples R3, 6 and 7 (collectively referred to as $\mathrm{R}_{\text {deep }} \mathrm{n}=3$ ) were considered to represent background samples for Site C. Sediment properties (Table S2 in the supplement) were generally similar between the $\mathrm{R}_{\text {shallow }}$ and $\mathrm{R}_{\text {deep }}$ zones. The exception to this was the percentage of fine grains in the sediment, which was significantly lower in $\mathrm{R}_{\text {shallow }}$ than in $\mathrm{R}_{\text {deep }}(t$-test: $t=-2.286, \mathrm{df}=10, \mathrm{p}<0.05)$. The $\mathrm{R}_{\text {shallow }}$ and $R_{\text {deep }}$ zones had similar levels of organic matter as well as hydrocarbon and heavy metal contamination (Table S2 in the supplement).

\section{Environmental variation resulting from disturbance}

In 2007, the environment beyond $100 \mathrm{~m}$ from the well was visually similar to typical undisturbed areas. Within $100 \mathrm{~m}$ of previous drilling, disturbance was visible (Fig. 3) as obvious cuttings piles with fine sediments of a lighter colour than background and, close to the drilling location, cement from the 'plug-andabandon' phase of the drilling operations (Fig. 4, Fig. S1 in the supplement at www.int-res.com/ articles/suppl/m461p071_supp.pdf). At Site A in 2004, there was an often gradual transition between complete cuttings coverage and natural seabed (area of complete cuttings $30700 \mathrm{~m}^{2}$; area of complete and partial cuttings $>70890 \mathrm{~m}^{2}$ ), with an extended area of partial cuttings (Jones et al. 2006). In this survey, the boundary between thick cuttings and typical seabed was much more distinct at both sites. The area impacted by complete cuttings at A (area of complete cuttings $5570 \mathrm{~m}^{2}$; area of complete and partial cuttings $10980 \mathrm{~m}^{2}$ ) had reduced from 2004 levels. In terms of distance, the extent of complete cuttings at A reduced to an average of $40 \mathrm{~m}$ from the drilling location, compared with $90 \mathrm{~m}$ in 2004. Conditions at Site C were similar to those found at A, with complete cuttings extending from the drill location to $18 \mathrm{~m}$ on average (area of complete cuttings $920 \mathrm{~m}^{2}$; area of complete and partial cuttings $2700 \mathrm{~m}^{2}$ ). The seabed was smothered by cuttings to a maximum depth of $1.5 \mathrm{~m}$, although typically of a lesser thickness.

\section{Response of megafaunal density}

Motile faunal density (Fig. 5) was generally a small percentage of total density (mean $11.1 \%$ at $\mathrm{R}_{\text {shallow }}$ ), but, taken alone, the densities of motile fauna were highly variable between samples. There was a significant influence of time since disturbance (year) on motile megafaunal densities in the shallow samples $(L$-ratio $=25.226, \mathrm{df}=1, \mathrm{p}<0.001)$, with both lower (0-100 m zone) and higher (100-200 m zone) densities in 2004 compared to 2007 surveys. The GLM 


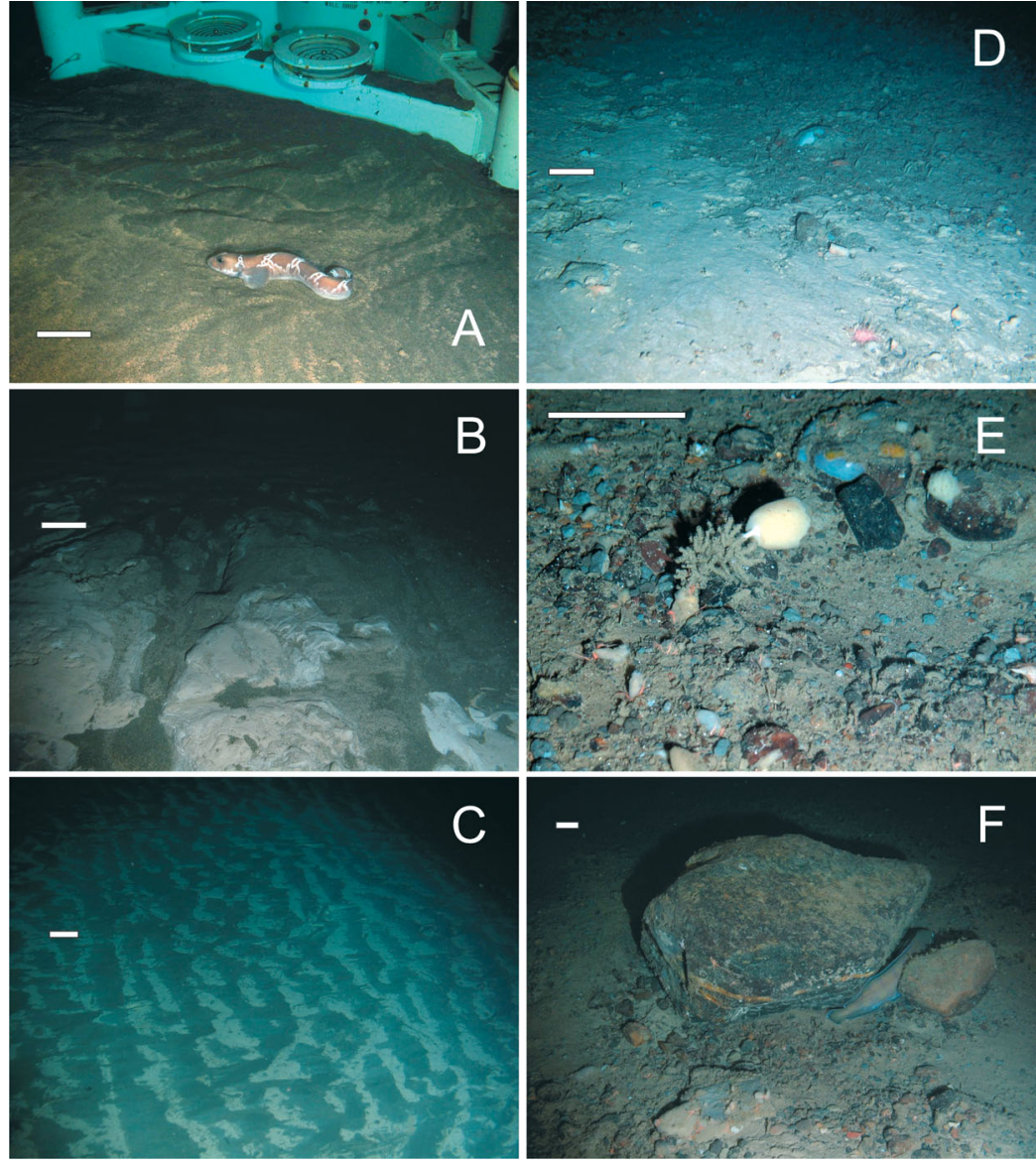

Fig. 4. Example images of disturbance regime at Laggan. (A) Seabed next to the blow-out preventer showing cuttings and Lycodes esmarkii, (B) area of complete cuttings and exposed cement, (C) complete cuttings area with ripples, (D) edge of cuttings, (E) normal seabed with gravel and pebbles, encrusting sponges and Stylocordyla borealis, (F) large iceberg-rafted boulder on normal seabed with Brosme brosme (species not seen on transect video). Scale bar = approximately $100 \mathrm{~mm}$ on the seafloor at its location

revealed an interaction of time since disturbance and distance in the shallow samples $(L$-ratio $=29.981, \mathrm{df}=$ $1, \mathrm{p}<0.001)$. In the shallow sites, motile organism densities were much more consistent in 2007 than in 2004, when density was very different between distance zones. This is taken to provide evidence of partial recovery between 2004 and 2007 in motile organism densities. Despite this, there was an influence of the distance (significant main effect) in both years $(L$-ratio $=151.361, \mathrm{df}=5, \mathrm{p}<0.001)$, with a general increase in density of motile fauna with increased distance (Fig. 5). There was a difference in motile megafaunal density between the shallow and deep water samples $(L$-ratio $=17.470, \mathrm{df}=1, \mathrm{p}<0.001)$, with generally greater densities of motile megafauna in the shallow samples. There was no significant interaction between the distance from drilling and the depth zone $(L$-ratio $=3.067, \mathrm{df}=5$, not significant [ns]).

Sessile fauna made up the majority of organisms found at Laggan (Fig. 5). There was a significant influence of time since disturbance on shallow sessile megafaunal densities ( $L$-ratio $=$ 140.803, df $=1, \mathrm{p}<0.001$ ), with increases in density in 2007 compared with 2004 surveys in the shallow samples. The GLM revealed an interaction of time since disturbance and distance in the shallow samples $(L$-ratio $=$ 11.373, $\mathrm{df}=1, \mathrm{p}<0.001)$. An increased time since drilling in the shallow samples led to greater densities of sessile organisms closer to the site of drilling, suggesting partial recovery between 2004 and 2007 in the densities of sessile megafauna. There was a weak influence of distance (model with 2004 and 2007 data) $(L$-ratio $=14.973, \mathrm{df}=5$, $\mathrm{p}<0.05$ ), revealing that densities of sessile organisms increased with increased distance from drilling in all samples investigated. There was a significant interaction between distance and depth zone $(L$-ratio $=49.349, \mathrm{df}=5$, $\mathrm{p}<0.001$ ), and the density of sessile benthic megafauna increased with increasing distance to a greater extent in shallow water than deep. This provides some evidence that there had been higher recovery in sessile benthic megafaunal densities after $10 \mathrm{yr}$ than after 3 . The model suggests that there were significantly higher sessile megafaunal densities in the deeper samples compared with those from shallower water $(L$-ratio $=58.189, \mathrm{df}=1, \mathrm{p}<0.001)$.

\section{Response of megafaunal diversity}

There were fewer motile taxa than sessile taxa at Laggan and the richness of motile taxa was less variable between sites (Table 3). The richness of motile organisms was not significantly different between the shallow and deep sites $(L$-ratio $=0.028, \mathrm{df}=1, \mathrm{~ns})$. Taxon richness in the shallow samples was virtually identical between 2004 and 2007 within a distance zone (Table 3). There was a significant main effect of distance on richness of motile organisms ( $L$-ratio $=$ 39.067, $\mathrm{df}=5, \mathrm{p}<0.001$ ), and richness increased with 

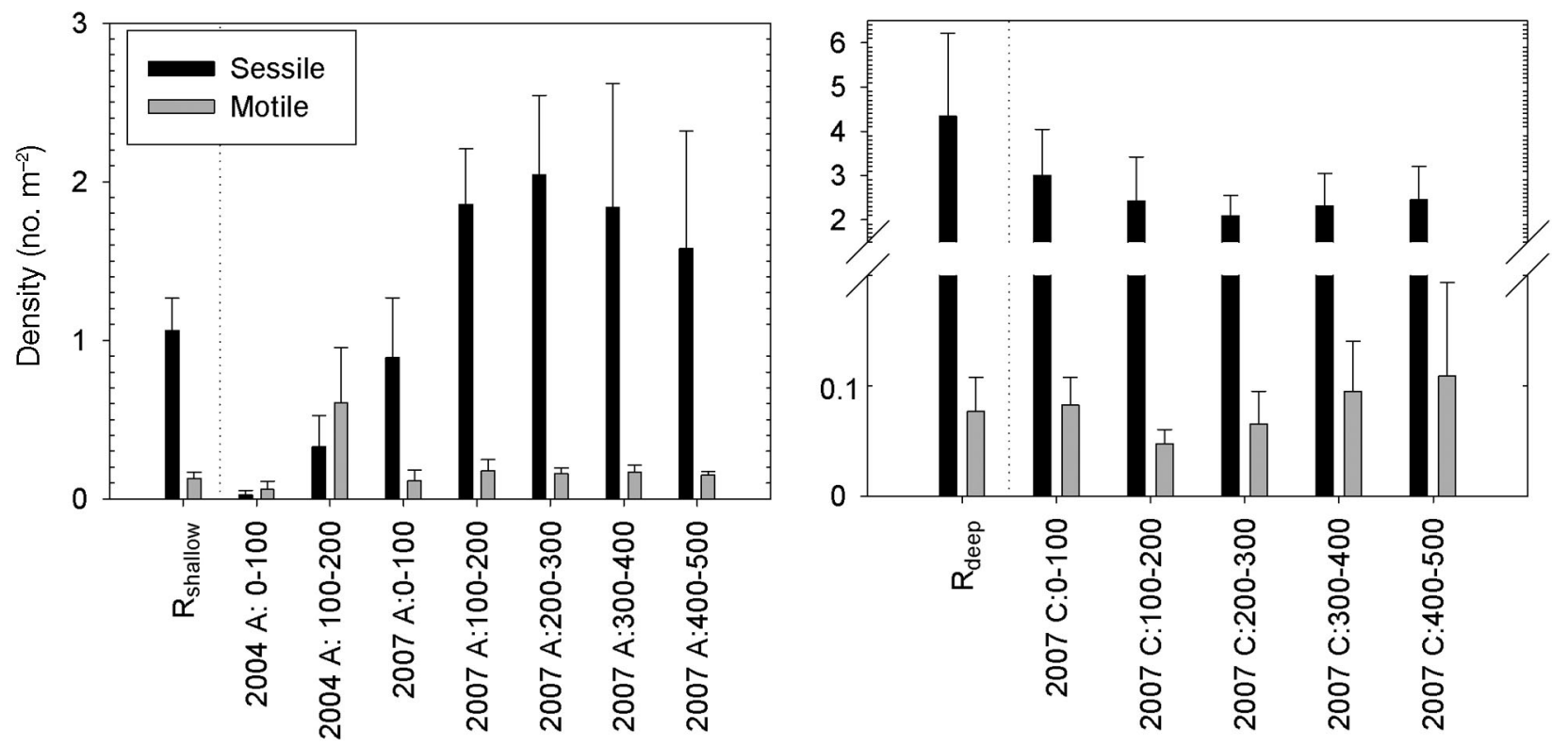

Fig. 5. Densities (no. $\mathrm{m}^{-2}$ ) of sessile and motile fauna under different disturbance regimes at Laggan. Error bars represent standard deviations. See Table 1 for definitions

Table 3. Variations in megafaunal species density and diversity measures around the Laggan site: density: no. $\mathrm{m}^{-2}$, mean $\pm \mathrm{SD}$; total taxa observed: $S_{\text {sessile }}=$ total number of unique sessile taxa in sample, $S_{\text {motile }}=$ total number of unique motile taxa in sample; $H^{\prime}=$ Shannon-Wiener index $\left[\log _{\mathrm{e}}\right]_{;} J^{\prime}=$ Pielou's evenness. $H^{\prime}$ included to provide comparison with other literature. All diversity indices were calculated from total numbers of each taxon for each station (i.e. several sampling units). $S$ is not adjusted for sampling effort. See Table 1 for other definitions

\begin{tabular}{|lrcrrrr|}
\hline & $\mathrm{n}$ & Density $\left(\right.$ no. $\mathrm{m}^{-2}$ ) & $S_{\text {sessile }}$ & $S_{\text {motile }}$ & $H^{\prime}$ & $J^{\prime}$ \\
\hline $\mathrm{R}_{\text {shallow }}$ & 8 & $1.19 \pm 0.02$ & 28 & 14 & 2.97 & 0.79 \\
$\mathrm{R}_{\text {deep }}$ & 3 & $4.41 \pm 0.63$ & 28 & 9 & 2.30 & 0.63 \\
2004 A: $0-100$ & 18 & $0.09 \pm 0.08$ & 6 & 10 & 2.23 & 0.81 \\
2004 A: $100-200$ & 18 & $0.94 \pm 0.43$ & 10 & 12 & 1.93 & 0.62 \\
2007 A: $0-100$ & 8 & $1.01 \pm 0.43$ & 22 & 10 & 2.71 & 0.78 \\
2007 A: $100-200$ & 8 & $2.03 \pm 0.40$ & 22 & 13 & 2.63 & 0.74 \\
2007 A: $200-300$ & 8 & $2.20 \pm 0.50$ & 22 & 15 & 2.64 & 0.73 \\
2007 A: $300-400$ & 8 & $2.01 \pm 0.76$ & 25 & 13 & 2.64 & 0.72 \\
2007 A: $400-500$ & 8 & $1.73 \pm 0.73$ & 23 & 14 & 2.68 & 0.74 \\
2007 C: $0-100$ & 4 & $3.09 \pm 1.05$ & 24 & 9 & 2.27 & 0.66 \\
2007 C: $100-200$ & 4 & $2.47 \pm 1.00$ & 26 & 9 & 2.31 & 0.66 \\
2007 C: $200-300$ & 4 & $2.15 \pm 0.49$ & 24 & 11 & 2.52 & 0.72 \\
2007 C: $300-400$ & 4 & $2.41 \pm 0.74$ & 24 & 13 & 2.46 & 0.68 \\
2007 C: $400-500$ & 4 & $2.56 \pm 0.82$ & 26 & 16 & 2.59 & 0.70 \\
\hline
\end{tabular}

distance from drilling in all samples. There was a significant interaction of distance zone and year in the richness of motile fauna in the shallow samples $(L$-ratio $=5.77, \mathrm{df}=1, \mathrm{p}<0.001)$. Although richness of motile taxa was lower on average in samples from the $0-100 \mathrm{~m}$ zone in $2004\left(S_{\text {mean motile }}=2.8\right)$ than in 2007 ( $\left.S_{\text {mean motile }}=3.8\right)$, sample richness in the $100-200 \mathrm{~m}$ zone was higher in $2004\left(S_{\text {mean motile }}=7.0\right)$ than in 2007 $\left(S_{\text {mean motile }}=5.3\right)$. There was no significant interaction of distance and depth group $(L$-ratio $=3.185, \mathrm{df}=5$, ns), suggesting that motile organisms did not recolonise the disturbed areas any more after $3 \mathrm{yr}$ than after $10 \mathrm{yr}$ of recovery time.

Taxon richness of sessile taxa varied between 6 and 28 (Table 3). There was a significant main effect of time since drilling on richness of sessile taxa $(L$-ratio $=156.084, \mathrm{df}=1, \mathrm{p}<$ 0.001 ), and taxon richness in the shallow samples was significantly lower in 2004 than in 2007. Richness of sessile organisms was lowest close to the well immediately after drilling (2004 A $0-100 \mathrm{~m} S_{\text {sessile }}=6$ ). Richness of sessile organisms increased with distance from drilling in all samples $(L$-ratio $=19.716, \mathrm{df}=5, \mathrm{p}<0.01)$. Both distance zones in 2004 had lower richness of sessile megafauna than $\mathrm{R}_{\text {shallow }}$ and any of the $2007 \mathrm{~A}$ zones (Table 3), supporting major reduction in sessile taxon richness as a result of drilling. In the zone closest to the well $(0-100 \mathrm{~m})$ in 2007, richness of sessile organisms ( $\left.S_{\text {sessile }}\right)$ had increased nearly 4 times from 2004 levels. This area still had significantly lower 
richness than either $\mathrm{R}_{\text {shallow }}$ or the areas further from disturbance in 2007 (Table 3), indicating incomplete recovery. None of the sessile taxa missing from the 2007 A 0-100 $\mathrm{m}$ zone but present in $\mathrm{R}_{\text {shallow }}$ were common in $\mathrm{R}_{\text {shallow }}$ (Table 1). There was a significant interaction of distance and year $(L$-ratio $=23.212$, $\mathrm{df}=$ $1, \mathrm{p}<0.001)$, and in the shallow samples, increased time since drilling led to greater richness of sessile organisms closer to the site of drilling. There was no significant interaction of distance and depth group $(L$-ratio $=2.021, \mathrm{df}=5, \mathrm{~ns})$.

Evenness (measured by $J^{\prime}$ ) was similar between samples taken in 2007 (Table 3). The 2004 samples at 0-100 $\mathrm{m}$ from drilling had the highest evenness $\left(\mathrm{J}^{\prime}=\right.$ 0.81). This was higher than the 2004 A $100-200 \mathrm{~m}$ samples, which had the lowest evenness $\left(J^{\prime}=0.62\right)$. Evenness was higher at $\mathrm{R}_{\text {shallow }}\left(J^{\prime}=0.79\right)$ than at $\mathrm{R}_{\text {deep }}\left(J^{\prime}=0.63\right)$. There were no significant differences in evenness with any of the explanatory variables investigated.

\section{DISCUSSION}

\section{Community heterogeneity at Laggan}

The megafaunal assemblage at Laggan was spatially variable; at least 2 major assemblage types were identified. The high spatial variability of the Faroe-Shetland Channel makes assessment of the potential environmental impact of developments more difficult. Water depth and proportion of fine sediments were shown to be important for structuring assemblages in background sites here and in other studies in the Faroe-Shetland Channel (Bett 2001, Jones et al. 2007a) and elsewhere (Tecchio et al. 2011). The variable temperature gradient in the Faroe-Shetland Channel (Turrell et al. 1999) may have exposed the shallow sites to higher temperatures than the deeper sites. Extreme bottom water temperature variation appears to be limited to $<600 \mathrm{~m}$ depth in this area (Turrell et al. 1999). Deeper than approximately $600 \mathrm{~m}$, continually cold conditions, characteristic of Faroe-Shetland Channel bottom water, persist (Turrell et al. 1999). In the Laggan region this boundary was probably slightly deeper than suggested. Most identified taxa were Arctic forms, typical of the deep FaroeShetland Channel (Jones et al. 2007a), Norwegian Sea (Dahl et al. 1976) and higher latitude areas (Mayer \& Piepenburg 1996, Piepenburg \& Schmid 1996, Starmans et al. 1999, Piepenburg et al. 2001).

\section{Effects of disturbance on megafauna}

At Laggan, the initial disturbance by physical smothering and burial of organisms was severe within $100 \mathrm{~m}$ of drilling activity, as observed for other forms of physical smothering disturbance (Stronkhorst et al. 2003). Outside the area of complete disturbance, megafaunal taxa responded differently to disturbance, likely dependant on a complex interaction of factors including feeding mode, motility, particle removal rate and rate of sedimentation (Nichols et al. 1978). Mobile scavengers, such as Atlantopandalus propinqvus and Pagurus sp., moved back into the area quickly to feed on moribund organisms. At this point, there was a relatively wide impacted area, where seabed disturbance was visible as fine sediment on the seafloor up to at least $250 \mathrm{~m}$ from the drilling activity.

Removal of cuttings at Laggan probably took place over time by lateral advection during high current events (velocities up to $1 \mathrm{~m} \mathrm{~s}^{-1}$; Masson et al. 2004) and from vertical redistribution in the sediments from bioturbation by abundant infaunal deposit feeders (Total E \& P UK pers. comm.). After 3 yr, there was significant removal of cuttings from those initially deposited, particularly in the areas with relatively low initial deposition.

After $3 \mathrm{yr}$, faunal density within $100 \mathrm{~m}$ of the well had increased considerably and was no longer significantly different from conditions further away. Motile megafauna were no longer elevated close to drilling. This response occurs rapidly in shallow water megafauna after disturbance from fishing (Ramsay et al. 1998). Slow recovery of megafauna appears typical from the limited studies in both hard (Althaus et al. 2009) and soft substrata (Bluhm 2001) in the deep oceans. Deep-sea invertebrates are long-lived and slow growing (e.g. Gage 1991, Tracey et al. 2007), so sessile fauna may take a long time to reach megafaunal sizes after recolonisation. Only 2 species found at Laggan have published growth rates, both mobile animals from the nearby, but warmer, Rockall Trough. It took at least $10 \mathrm{yr}$ for a echinoid found at Laggan, Echinus elegans, to reach $50 \mathrm{~mm}$ test diameter (Gage et al. 1986) and at least 5 yr for an ophiuroid, Ophiocten gracilis, common in samples at Laggan (and therefore probably included in the 'indeterminate ophiuroids' enumerated on video) to reach a disc diameter of $7 \mathrm{~mm}$ (Gage 2003), which equates to approximately $50 \mathrm{~mm}$ total diameter (including arms). More detailed studies are required to determine the source of recruits to areas disturbed by drilling activity. 
The 2007 A $0-100 \mathrm{~m}$ samples showed that there were still megafaunal taxa that were displaced by disturbance, but the relative proportion of taxa was not clearly affected. As overall density of sessile organisms was low and only rarer taxa were absent from the more disturbed area in 2007, the reduced richness observed may have resulted from the reduced probability of sampling the rarer taxa (Magurran 2003). In 2007, the boulders that had harboured the majority of the organisms in the disturbed zones in 2004 (Jones et al. 2006) were observed again; however, they were no longer supporting an epilithic community, suggesting a chronic and ultimately lethal effect of either physical smothering from the initial sedimentation event (Nichols et al. 1978) or chemical influence from the drill cuttings (Terzaghi et al. 1998, Trannum et al. 2010).

After 10 yr at C, seabed disturbance was still visible close to the well and appeared similar to that found at A after 3 yr. This suggests a proportion of the deposited cuttings were resistant to erosion, probably owing to the presence of cement. There was still limited megafaunal recolonisation in this area. However, within $10 \mathrm{~m}$ of the disturbed area, there was an abundant, diverse megafaunal community, not readily distinguishable from that found over $100 \mathrm{~m}$ from the drilling location. A similar response occurred in the DISCOL deep-sea disturbance experiment (Bluhm 2001), where soft sediment megafaunal recovery was evident after $7 \mathrm{yr}$, although there were still small differences in the taxonomic and numerical composition of megafauna. There were probably also some species-specific responses to observed variable sediment levels and chemical concentrations found around the drilling location at Laggan (e.g. elevated barium was found in some samples near to Well A and C in 2007, Total E \& P UK pers. comm.), but the heterogeneous seabed, irregular chemical distribution and naturally highly variable megafauna make these subtle effects difficult to distinguish.

Disturbance from drilling is known to affect the functioning of benthic communities (Schaanning et al. 2008, Trannum et al. 2010). Species diversity and density of the megafaunal assemblage likely correlate with the ecosystem functions they provide (Danovaro et al. 2008), suggesting little appreciable change in function beyond $100 \mathrm{~m}$ from the disturbance. It would be extremely valuable to evaluate functional changes beyond these generalisations. Some sessile taxa, particularly the sponges, may be suitable as species indicating functional recovery of a given area in space and time. The best specific example of this is the spherical sponge, which is conspicu- ous and occurs at high densities in areas with low disturbance. Although their abundance decreased, they were not completely absent in disturbed areas. Further work is also required to understand potential functional change within smaller size fractions of the benthos (e.g. the bacteria, meio- and macrofauna), which may differ from the megafauna in their response to disturbance. Recovery potential from anthropogenic disturbance in the deep sea remains relatively unknown. Further study, using high-resolution methodologies, of community patterns and the ecology of key deep-water species is required at background sites as anthropogenic activity in the deep-sea realm continues to increase.

\section{CONCLUSIONS}

This study indicates that deep-water megafaunal density and diversity recovers partially from drilling disturbance after 3 yr. However, although there is increased recovery after $10 \mathrm{yr}$, drill cuttings and associated impacts on epibenthic megafaunal assemblages are still distinguishable after a decade. Megafauna may recover more slowly than the more commonly studied smaller infauna. Carefully designed, high-resolution and multi-year studies, such as this, are rare but essential to further our understanding of recovery from anthropogenic impact.

Acknowledgements. We thank Total E \& P UK and the Total Corporate Foundation for Biodiversity and the Sea for hosting this work and providing valuable assistance throughout. Thanks also to Fugro and the staff of the MV 'Fugro Mercator' for assistance at sea. Particular thanks to I. Park, W. Brown, P. Collins and A. Hughes for help. This document was improved with constructive comments from B. Bett, D. Mayor, B. Wigham and 3 anonymous reviewers. The work was carried out as part of the SERPENT and DIEPS (Deep-water Industry, Environment, Policy and Science) projects. D.O.B.J. was funded by NERC DIEPS grant NE/C508518/1 and as part of the NERC Marine Environmental Mapping Programme (MAREMAP). SERPENT was funded for this work by a grant from the Total Corporate Foundation for Biodiversity and the Sea.

\section{LITERATURE CITED}

Althaus F, Williams A, Schlacher TA, Kloser RJ and others (2009) Impacts of bottom trawling on deep-coral ecosystems of seamounts are long-lasting. Mar Ecol Prog Ser 397:279-294

Bett BJ (2001) UK Atlantic margin environmental survey: Introduction and overview of bathyal benthic ecology. Cont Shelf Res 21:917-956

Bluhm H (2001) Re-establishment of an abyssal megabenthic community after experimental physical disturbance of the seafloor. Deep-Sea Res II 48:3841-3868 
Dahl E, Laubier L, Sibuet M, Stroemberg JO (1976) Some quantitative results on benthic communities of the deep Norwegian Sea. Astarte 9:61-79

$>$ Danovaro R, Gambi C, Dell'Anno A, Corinaldesi C and others (2008) Exponential decline of deep-sea ecosystem functioning linked to benthic biodiversity loss. Curr Biol 18:1-8

Dobson AJ, Barnett AG (2008) An introduction to generalized linear models. Chapman \& Hall, London

Fox J, Weisberg S (2011) An $\{r\}$ companion to applied regression, second edition. Sage, Thousand Oaks, CA

Gage JD (1991) Biological rates in the deep sea: a perspective from studies on processes in the benthic boundary layer. Rev Aquat Sci 5:49-100

$>$ Gage JD (2003) Growth and production of Ophiocten gracilis (Ophiuroidea: Echinodermata) on the Scottish continental slope. Mar Biol 143:85-97

$>$ Gage JD, Tyler PA, Nichols D (1986) Reproduction and growth of Echinus acutus var norvegicus Duben and Koren and Echinus elegans Duben and Koren on the continental slope off Scotland. J Exp Mar Biol Ecol 101:61-83

> Hughes SJM, Jones DOB, Hauton C, Gates AR, Hawkins LE (2010) An assessment of drilling disturbance on Echinus acutus var. norvegicus based on in-situ observations and experiments using a remotely operated vehicle (ROV). J Exp Mar Biol Ecol 395:37-47

> Jones DOB (2009) Using existing industrial remotely operated vehicles for deep-sea science. Zool Scr 38:41-47

Jones DOB, Gates AR (2010) Deep-sea life of Scotland and Norway. Ophiura, Southampton

Jones DOB, Hudson IR, Bett BJ (2006) Effects of physical disturbance on the cold-water megafaunal communities of the Faroe-Shetland Channel. Mar Ecol Prog Ser 319:43-54

Jones DOB, Bett BJ, Tyler PA (2007a) Megabenthic ecology of the Faroe-Shetland Channel: a photographic study. Deep-Sea Res I 54:1111-1128

> Jones DOB, Wigham BD, Hudson IR, Bett BJ (2007b) Anthropogenic disturbance of deep-sea megabenthic assemblages: a study with remotely-operated vehicles in the Faroe-Shetland Channel, NE Atlantic. Mar Biol 151: 1731-1741

Magurran AE (2003) Measuring biological diversity. Blackwell Science, Oxford

Masson DG, Wynn RB, Bett BJ (2004) Sedimentary environment of the Faroe-Shetland and Faroe Bank Channels, north-east Atlantic, and the use of bedforms as indicators of bottom current velocity in the deep ocean. Sedimentology 51:1207-1241

Mayer M, Piepenburg D (1996) Epibenthic community patterns on the continental slope off east Greenland at $75^{\circ}$ N. Mar Ecol Prog Ser 143:151-164

Narayanaswamy BE, Bett BJ, Gage JD (2005) Ecology of bathyal polychaete fauna at an Arctic-Atlantic boundary (Faroe-Shetland Channel, north-east Atlantic). Mar Biol Res 1:20-32

Nichols JA, Rowe GT, Clifford CH, Young RA (1978) In situ experiments on the burial of marine invertebrates. J Sediment Petrol 48:419-425

O’Neill R (1998) Recovery in complex ecosystems. J Aquat Ecosyst Stress Recovery 6:181-187

- Piepenburg D, Schmid MK (1996) Distribution, abundance, biomass, and mineralization potential of the epibenthic megafauna of the Northeast Greenland shelf. Mar Biol 125:321-332

Editorial responsibility: Paul Snelgrove,

St. John's, Newfoundland and Labrador, Canada
Piepenburg D, Brandt A, von Juterzenka K, Mayer M and others (2001) Patterns and determinants of the distribution and structure of benthic faunal assemblages in the northern North Atlantic. In: Schafer P, Ritzrau M, Schluter M, Thiede J (eds) The northern North Atlantic: a changing environment. Springer, Berlin, p 179-198

R Development Core Team (2010) R: A language and environment for statistical computing. R Foundation for Statistical Computing, Vienna www.R-project.org

Radler M (2006) Oil production, reserves increase slightly in 2006. Oil Gas J 104:20-23

> Ramsay K, Kaiser MJ, Hughes RN (1998) Responses of benthic scavengers to fishing disturbance by towed gears in different habitats. J Exp Mar Biol Ecol 224:73-89

Santos MFL, Lana PC, Silva J, Fachel JG, Pulgati FH (2009) Effects of non-aqueous fluids cuttings discharge from exploratory drilling activities on the deep-sea macrobenthic communities. Deep-Sea Res II 56:32-40

Schaanning MT, Trannum HC, Øxnevad S, Carroll J, Bakke $\mathrm{T}$ (2008) Effects of drill cuttings on biogeochemical fluxes and macrobenthos of marine sediments. J Exp Mar Biol Ecol 361:49-57

Sherwin T (1995) Tidal oscillations of the thermocline in the Faroe-Shetland Channel. Ocean Challenge 6:33-35

- Smith CR, Hamilton SC (1983) Epibenthic megafauna of a bathyal basin off southern California: Patterns of abundance, biomass, and dispersion. Deep-Sea Res 30: 907-928

Starmans A, Gutt J, Arntz WE (1999) Mega-epibenthic communities in Arctic and Antarctic shelf areas. Mar Biol 135:269-280

Stronkhorst J, Ariese F, van Hattum B, Postma JF and others (2003) Environmental impact and recovery at two dumping sites for dredged material in the North Sea. Environ Pollut 124:17-31

- Tecchio S, Ramírez-Llodra E, Sardà F, Company JB and others (2011) Drivers of deep Mediterranean megabenthos communities along longitudinal and bathymetric gradients. Mar Ecol Prog Ser 439:181-192

Terzaghi C, Buffagni M, Cantelli C, Bonfanti P, Camatini M (1998) Physical-chemical and ecotoxicological evaluation of water based drilling fluids used in Italian off-shore. Chemosphere 37:2859-2871

Thomson CW (1873) The depths of the sea. MacMillan, London

Tracey DM, Neil H, Marriott P, Andrews AH, Cailliet GM, Sanchez JA (2007) Deep-sea scleractinian coral age and depth distributions in the northwest Atlantic for the last 225, 000 years. Bull Mar Sci 81:371-391

> Trannum HC, Nilsson HC, Schaanning MT, Øxnevad S (2010) Effects of sedimentation from water-based drill cuttings and natural sediment on benthic macrofaunal community structure and ecosystem processes. J Exp Mar Biol Ecol 383:111-121

- Turrell WR, Slesser G, Adams RD, Payne R, Gillibrand PA (1999) Decadal variability in the composition of FaroeShetland Channel bottom water. Deep-Sea Res I 46:1-25

> Underwood AJ (1994) On beyond BACI: sampling designs that might reliably detect environmental disturbances. Ecol Appl 4:3-15

Witbaard R, Daan R, Mulder M, Lavaleye M (2005) The mollusc fauna along a depth transect in the Faroe Shetland Channel: Is there a relationship with internal waves? Mar Biol Res 1:186-201

Submitted: January 27, 2012; Accepted: May 21, 2012

Proofs received from author(s): August 1, 2012 